\title{
Cryopreserved ovarian tissues can maintain a long-term function after heterotopic autotransplantation in rat
}

\author{
Xiaohui Deng, Hua Zheng, Xuan Yu, Hongling Yu, Chengmei Zhang ${ }^{1}$, Lan Chao, \\ Ruichang Li and Wenjun Liu $^{2}$
}

Center for Reproductive Medicine, Qilu Hospital of Shandong University, Jinan 250012, Shandong, People's Republic of China, ${ }^{1}$ Laboratory Animal Center of Shandong University, Jinan 250012, Shandong, People's Republic of China and ${ }^{2}$ Department of Pathology, Qilu Hospital of Shandong University, Jinan 250012, Shandong, People's Republic of China

Correspondence should be addressed to X Deng; Email: dxh122@yahoo.cn

\begin{abstract}
The functional longevity of cryopreserved ovarian grafts is one of the most challenging questions regarding ovarian transplantation at present. This study used a rat ovarian grafting model to investigate whether ovarian tissues from adult rats, which had been cryopreserved by vitrification and followed by heterotopic transplantation, could establish long-term hormone secretion and follicle development. Fresh and cryopreserved ovarian tissues were autologously transplanted under the kidney capsule. One-third of the animals in each group (sham-operated, fresh autografts, cryopreserved autografts, or castrated) were killed 5, 8, or 10 months after transplantation. Vaginal cytology, serum estradiol $\left(E_{2}\right)$, progesterone, and the morphology of the reproductive tract were used to assess ovarian function. Both fresh and cryopreserved ovarian grafts survived well in all the animal models with comparable proportion of follicles at each stage of folliculogenesis at all three time points. The serum $E_{2}$ and progesterone concentrations in the groups with fresh or cryopreserved grafts remained comparable with those in sham-operated controls at all investigated time points. However, a loss of grafts and primordial follicles following heterotopic transplantation was noted. In conclusion, the heterotopic autotransplantation of vitrified ovarian tissues from adult rat without vascular anastomosis can maintain long-term ovarian function and exert endocrine function in target organs, in spite of the reduction in follicle pool.
\end{abstract}

Reproduction (2009) 138 519-525

\section{Introduction}

Cancer treatments, including chemotherapy, radiotherapy, and radical surgery, induce premature menopause and infertility in many of the hundreds of thousands of women who are still at their reproductive age every year. Counteracting the deterioration of ovarian function and maintaining their fertility has become an important goal for female cancer patients. One possible way to preserve fertility is to cryopreserve the ovarian tissue for later transplantation before treatments (Oktay et al. 2004).

Parrott (1960) demonstrated that frozen ovarian fragments could restore fertility of mice when autografted, albeit at a low rate. Over 50 years ago, only $\sim 5 \%$ of the follicle population survived the freezethawing process compared with fresh ovarian tissues, with primordial follicles (PmFs) being the sole survivors (Green et al. 1956). Animal experiments now suggest that $87 \%$ of PmFs survive with normal ultrastructure following vitrification (Chen et al. 2006), and that cryopreservation does not affect the long-term viability of ovarian tissue (Candy et al. 2000) and therefore provides an option for storing female germ cells in ovarian tissue banks. Studies in humans demonstrate that fertility and ovarian endocrine function can be preserved for women by grafts of cryopreserved ovarian tissue (Donnez et al. 2004, Oktay et al. 2004, Smitz \& Cortvrindt 2004, Demeestere et al. 2007, Andersen et al. 2008).

Ovarian tissue transplantation preserves both steroidogenic and gametogenic functions. The birth of animals using this technique confirmed that the fresh and frozen ovarian tissue grafts that had been orthotopically or heterotopically autotransplanted restored cyclic hormonal function and fertility (Candy et al. 2000, Lee et al. 2004, Waterhouse et al. 2004, Liu et al. 2008). As to the long-term functions of grafts, Baird et al. (1999) demonstrated that despite drastic reduction in the pool of oocytes, cyclical ovarian function was observed for nearly 2 years after cryopreserved ovarian tissue transplantation in sheep. But the results from another 
Table 1 The hormone values during the estrus in groups A, B, and C and at the time of death in group D (mean \pm s.E.M).

\begin{tabular}{|c|c|c|c|c|c|c|c|}
\hline \multirow[b]{2}{*}{ Groups } & \multirow[b]{2}{*}{$\begin{array}{c}\text { Number } \\
\text { of rats }\end{array}$} & \multicolumn{2}{|c|}{ 5th Month } & \multicolumn{2}{|c|}{ 8th Month } & \multicolumn{2}{|c|}{ 10th Month } \\
\hline & & $\mathrm{E}_{2}(\mathrm{pg} / \mathrm{ml})$ & $\mathrm{P}(\mathrm{ng} / \mathrm{ml})$ & $\mathrm{E}_{2}(\mathrm{pg} / \mathrm{ml})$ & $\mathrm{P}(\mathrm{ng} / \mathrm{ml})$ & $\mathrm{E}_{2}(\mathrm{pg} / \mathrm{ml})$ & $\mathrm{P}(\mathrm{ng} / \mathrm{ml})$ \\
\hline A & 5 & $69.750 \pm 10.050$ & $10.533 \pm 3.838$ & $67.433 \pm 10.629$ & $11.667 \pm 2.361$ & $68.283 \pm 10.500$ & $11.667 \pm 3.535$ \\
\hline $\mathrm{B}$ & 8 & $65.963 \pm 11.890$ & $10.863 \pm 2.459$ & $66.788 \pm 10.855$ & $9.862 \overline{5} \pm 2.838$ & $63.950 \pm 10.943$ & $11.600 \pm 4.178$ \\
\hline $\mathrm{C}$ & 8 & $63.625 \pm 10.648$ & $9.625 \pm 3.826$ & $65.813 \pm 11.661$ & $11.013 \pm 3.951$ & $62.725 \pm 8.144$ & $9.588 \pm 3.437$ \\
\hline $\mathrm{D}$ & 5 & $19.140 \pm 4.440^{*}$ & $1.920 \pm 0.415^{*}$ & $14.780 \pm 4.729^{*}$ & $1.780 \pm 0.466^{*}$ & $13.480 \pm 4.082^{*}$ & $1.600 \pm 0.400^{*}$ \\
\hline
\end{tabular}

* Statistically lower than groups A, B, and C $(P<0.01)$.

experiment in rats indicated that the transplanted ovaries without vascular pedicle were nonfunctional at 6 and 12 months according to the morphometric changes and serial hormone measurements (Callejo et al. 2002).

The case reports from clinical studies suggested that hormonal production could be restored after fresh or cryopreserved heterotopic ovarian tissue transplantation in women, but that this function remained only for a short period (Callejo et al. 2001). However, fresh orthotopic ovarian cortex transplantation has maintained normal ovarian function beyond 2 years in $75 \%$ of patients (Sanchez et al. 2007).

Challenging questions regarding ovarian transplantation currently include the survival rate of the grafts, their functional longevity, the optimal cryopreservation method, and the optimal graft site and size. Therefore, this study used a rat model to assess long-term function by vitrified ovarian autografts placed at a heterotopic site.

\section{Results}

\section{Vaginal cytology}

Daily vaginal irrigation showed completely cornified epithelial cells in all group A rats, and they appeared in rats receiving fresh ovarian grafts (group B), and cryopreserved grafts (group C) by $7-11$ days and 8-11 days respectively after the grafting. In group C, no significant variation of vaginal cytology was noticed during the 2-week-period that their ovaries were in liquid nitrogen. There were no cyclical changes in vaginal irrigation samples from the ovariectomized rats (group D), but a large number of leukocytes with a few cornified epithelial cells and cell debris appeared continuously.

\section{Hormone values}

The serum estradiol-17 $\left(\mathrm{E}_{2}\right)$ and progesterone concentrations in estrus females in groups $\mathrm{B}$ and $\mathrm{C}$ were comparable with those in the sham-operated group (group A), and significantly higher than in the ovariectomized control (group D) at 5, 8 and 10 months $(P<0.01)$. No statistically significant differences were found in serum $E_{2}$ and progesterone concentrations between groups $B$ and $C$ at any time point $(P>0.05$; Table 1$)$.

\section{Morphology of the grafts and uteri}

The grafts in groups $B$ and $C$ survived under the renal capsule. They were easily identified and showed a morphologically similar appearance. Blood vessels surrounding the grafts were visible. Cysts full of liquid were observed on the surface of some grafts (Fig. 1). There was no significant difference in the mean number of recovered grafts between groups $B$ and $C$ at 5,8 , or 10 months after transplantation $(P>0.05)$. In both groups, the mean number of recovered grafts at 5 month was significantly higher than that at 8 and 10 months $(P<0.05$; Table 2$)$. The uteri of all the females in groups $B$ and $C$ were of normal size and appearance in contrast to the uteri of the females in group $\mathrm{D}$, which were greatly reduced in size and weight (Fig. 2a-C). The mean uterine weight in group $D$ was significantly lower than that in groups $\mathrm{A}, \mathrm{B}$, and $\mathrm{C}(P<0.05$; Fig. 3$)$. The mean weight of the rats in group $D$ was significantly higher than that in the other groups after the 8 month $(P<0.05$; Fig. 4).

\section{Histological analysis of ovarian tissue and endometrium}

The cryopreserved and grafted tissues all appeared morphologically normal under the light microscope although there were a few cysts in some grafted tissues. Blood clots were present in structures that may have been freshly formed corpora lutea. Newly established blood vessels had grown into the ovarian tissue from the surface of the kidney. In groups A, B, and C, the uteri

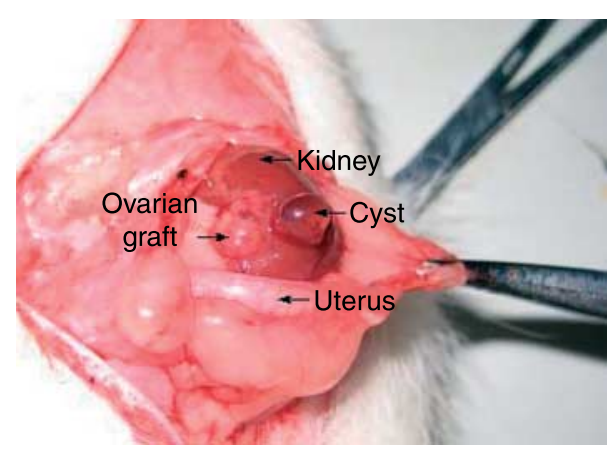

Figure 1 The uterus and cryopreserved ovarian grafts under the kidney capsule after 8 months. 
Table 2 Summary of the number of grafts (mean \pm S.E.M.) recovered from each rat in groups B and C.

\begin{tabular}{|c|c|c|c|c|c|}
\hline \multirow[b]{2}{*}{ Time } & \multirow[b]{2}{*}{$\begin{array}{c}\text { Number } \\
\text { of rats }\end{array}$} & \multicolumn{2}{|c|}{ Group B } & \multicolumn{2}{|c|}{ Group C } \\
\hline & & Number of pieces & $\begin{array}{l}\text { Percentage of } \\
\text { implanted (\%) }\end{array}$ & Number of pieces & $\begin{array}{l}\text { Percentage of } \\
\text { implanted (\%) }\end{array}$ \\
\hline 5th Month & 8 & $8.875 \pm 0.9910$ & 74 & $8.500 \pm 1.1952$ & 71 \\
\hline 8th Month & 8 & $6.375 \pm 1.9226^{*}$ & 53 & $6.500 \pm 1.5119^{*}$ & 54 \\
\hline 10th Month & 8 & $5.625 \pm 2.4458^{*}$ & 47 & $5.875 \pm 2.1002^{*}$ & 49 \\
\hline
\end{tabular}

*Significantly lower than after 5 months $(P<0.05)$.

appeared functional as judged by the abundance of glands. By contrast, the uteri of animals in group D appeared atrophic and contained few glands, and had less thick simple columnar epithelium (Fig. 5a-j).

\section{Evaluation of follicles}

The proportion of follicles at each stage of folliculogenesis was not significantly different between fresh and cryopreserved ovarian tissues before grafting $(P>0.05)$, or between the groups $A, B$, and $C$ at the same time point $(P>0.05)$. In groups $A, B$, and $C$, the grafts contained comparable proportion of follicles at each developmental stage at the different time points $(P>0.05)$. The percentage of tertiary follicles (TFs) was significantly higher in group $\mathrm{C}$ at any time points compared with cryopreserved tissue before grafting $(P<0.05$; Table 3$)$. The loss of PmFs in the recovered grafted tissues was noted, with $\sim 40.5 \%$ fewer PmFs in the fresh grafts and $44.9 \%$ fewer in the frozen grafts compared with the sham-operated group at 5 month after transplantation (Table 4).

\section{Discussion}

The ovaries of Wistar rats normally remain functional for about 18 months. The period of observation in this study was 5-10 months after ovarian transplantation, which covered more than half of their reproductive lifespan. Thus, the study could evaluate the long-term function of grafted ovarian tissues during a relatively short time. After heterotopic autotransplantation, the ovarian tissues survived well in both fresh and cryopreserved transplantation groups and revealed comparable proportion of follicles in each developmental stage at 5, 8, or 10 months after grafting. The results indicated that

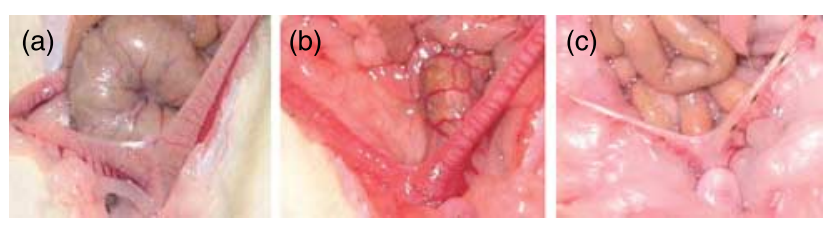

Figure 2 The appearance of the uteri after 10 months in (a) the sham operated group; (b) the cryopreserved grafted group; and (c) the castrated group. heterotopic autologous ovarian transplantations in our rat model were successful in all cases and maintained function for more than 10 months subsequently.

As the PmFs are abundant and developmentally dormant, the ovary is well suited for tissue storage. The trimmed ovarian tissue blocks were directly put into liquid nitrogen, maximizing the cooling rate, facilitating vitrification, and reducing ice crystal formation. When warming, the immersion of the vitrified tissues in dilution solution maximized the warming rate to minimize devitrification. This vitrification method has previously shown greater percentage of morphologically normal follicles in the histological examination, larger survival of follicles, and better ultrastructural preservation of PmFs, compared with conventional vitrification and slow freezing (Chen et al. 2006). In this study, we found that in cryopreserved ovarian tissues before grafting, the proportion of follicles at each stage of folliculogenesis was not significantly different from fresh ovarian tissues. Also there was no significant difference in the mean number of recovered grafts between the fresh and cryopreserved transplantation groups at 5, 8 or 10 months after transplantation. These results indicated that cryopreservation did not have an obviously detrimental effect on grafted ovarian function. Though not significant, the percentage of morphologically normal TFs in cryopreserved ovarian tissues was lower than that in fresh tissues before grafting. The cause of this decrease may be due to the larger size of follicles that was more difficult for sufficient dehydration and more easily destroyed during the trimming procedure. However, the small follicles in heterotopic grafts could develop further and the percentage of TFs increased significantly in cryopreserved grafts compared with the cryopreserved tissue before grafting.

Functional vessels within grafts have been detected in rats by day 3 (Dissen et al. 1994). In our study, estrus-like cytological variations were observed at $7-11$ days and 8-11 days respectively in groups $B$ and $C$. Both in groups $B$ and $C$, the uterus appeared healthy, and the mean uterine weight was similar to that of the control group and the endometrium showed secretory change as control group after transplantation. These illustrated that the perfused grafts secreted the hormones having an effect on its target organs through the new established vessels. The results showed that the serum $E_{2}$ and 


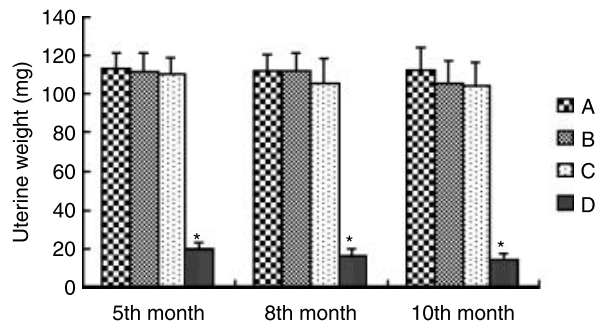

Figure 3 Uterine weights are shown as mean value \pm s.E.M. Uterine weights in group $\mathrm{D}$ are significantly lower than that in the other groups at all three time points, ${ }^{*} P<0.05$.

progesterone concentrations during estrus in groups B and $\mathrm{C}$ remained at a stable level, which was comparable with the sham-operated group (group A) in 10 months after transplantation.

Though the hormone levels remained stable, the mean numbers of recovered grafts decreased significantly from 5 months onward in both groups B and C, while Yang et al. (2006) reported that the recovery rate of fresh grafts after 3 weeks from the kidney capsule of mice was 93-95\%. Cysts filled with liquid were observed adjacent to a few grafts. The liquid might be follicular fluid that had not dissipated after ovulation. The aggregation of follicular fluid surrounding the grafts might alter the position of grafts, destroy the vascular supply, which is newly established, and therefore result in the degeneration of the grafts. The surviving grafts contained follicles at all stages of folliculogenesis and corpora lutea. The proportion of each stage follicles in both types of grafts was comparable with that in control group. All these results indicated that the follicles in heterotopic grafts could develop further. The presence of a blood clot could indicate a newly formed corpus luteum. However, it is not clear whether this indicates that follicles in the grafts can ovulate or form normal luteal tissue. (Dahm-Kähler et al. 2006, Boubekri et al. 2007).

A loss of PmFs in the recovered grafts was observed. Our study showed that $59.5 \%$ of the PmFs remained in the fresh ovarian grafts and $55.1 \%$ in the cryopreserved ovarian grafts compared with the control group at 5 months after transplantation. Although small ovarian blocks made close contact with the graft site, promoting the revascularization and facilitating the perfusion of the grafts, a lot of follicles in every folliculogenesis stage

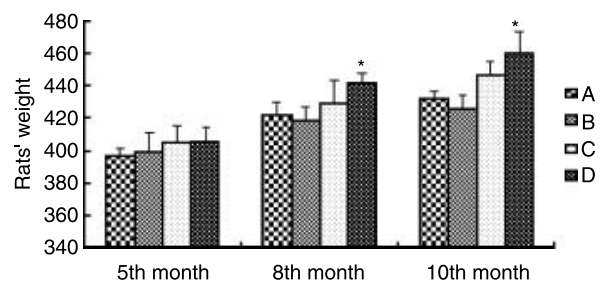

Figure 4 Rats' weights are shown as mean value \pm S.E.M. The mean weight of the rats in group $D$ was significantly higher than that in the other groups after 8 months, ${ }^{*} P<0.05$. were inevitably lost when the ovaries were trimmed into blocks. This substantial loss of follicles was observed in studies on mice and larger animal models (Baird et al. 1999, Liu et al. 2002). The loss of grafts and the decrease in the follicle pool might shorten the longevity of ovarian function after grafting.

Few studies have investigated long-term function of transplanted ovarian tissue. The clinical cases suggested that hormonal protection can be restored after fresh or cryopreserved heterotopic ovarian transplantation in women for more than 1 year, but the reproductive span only lasted for a short period (Callejo et al. 2001). Longterm ovarian function (lasting for 15-41 months) was established in three patients after heterotopic
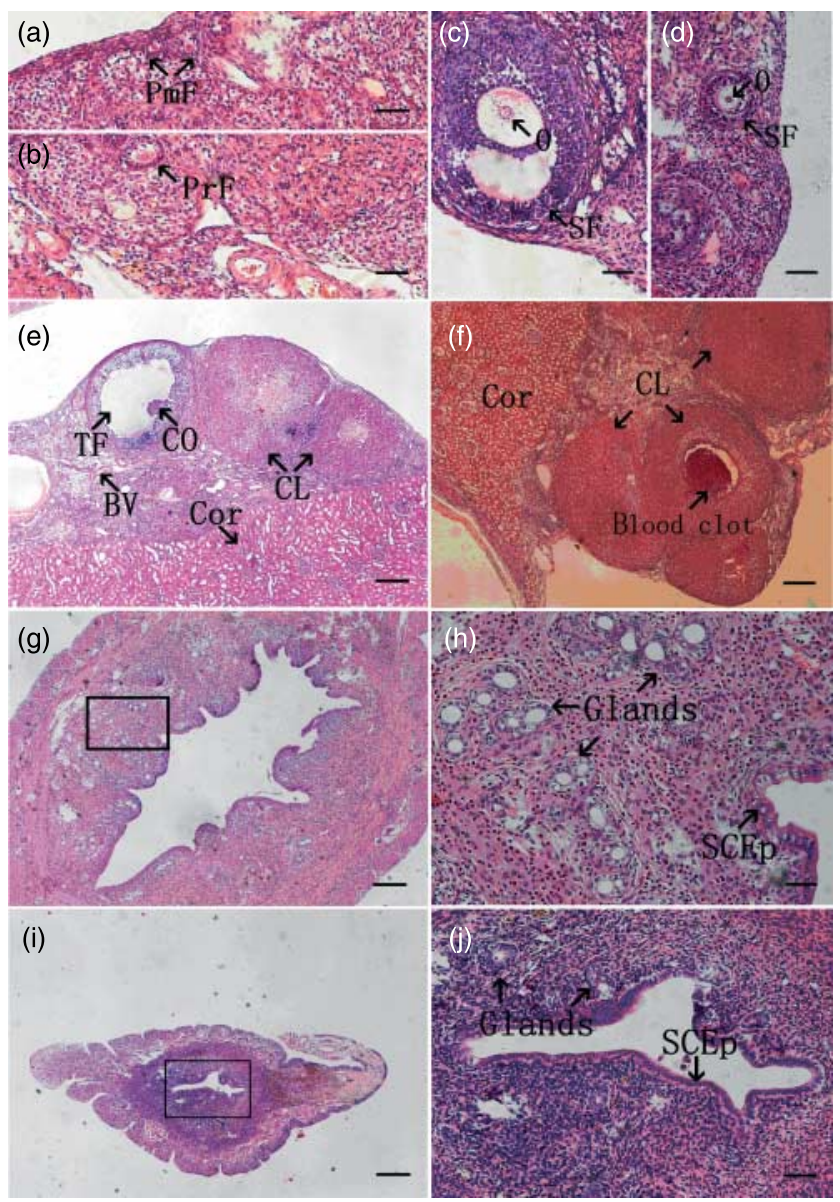

Figure 5 Histology of grafts and endometrium. (a) Primordial follicles (PmF) in a cryopreserved graft after 10 months. (b) A primary follicle (PrF) in cryopreserved graft after 8 months. (c) A secondary follicle (SF) with an irregular antrum and a clearly visible oocyte in group $B$ graft after 8 months. (d) A secondary follicle without an antrum in group $C$ after 8 months. (e) A cryopreserved graft adjacent to the renal cortex (Cor) after 5 months containing newly established blood vessels (BV), several corpora lutea (CL), and a tertiary follicle (TF) with a cumulus oophorus (CO). (f) A newly formed corpus luteum with blood clot in a cryopreserved graft after 10 months. (g and h) A functional uterus in group $C$ after 5 months. (i and j) An atrophic uterus in group D 5 months after ovariectomy; (a-d, h, and j), magnified by 200, Bar, $250 \mu \mathrm{m}$; (e-g, and i), magnified by 40, Bar, $50 \mu \mathrm{m}$. 
Table 3 The number of primordial follicles (PmF), primary follicles (PrF), secondary follicles (SF), and tertiary follicles (TF) in the ovarian pieces according to groups.

\begin{tabular}{|c|c|c|c|c|c|c|}
\hline Groups & $\begin{array}{l}\text { Number } \\
\text { of pieces }\end{array}$ & PmF (\%) & $\operatorname{PrF}(\%)$ & SF $(\%)$ & TF (\%) & Total \\
\hline Fresh & 10 & $164(36.7)$ & $120(26.8)$ & $152(34.0)$ & $11(2.5)$ & 447 \\
\hline Cryopreserved & 16 & 247 (36.6) & $192(28.4)$ & $232(34.4)$ & $4(0.6)$ & 675 \\
\hline $\begin{array}{l}\text { 5th Month } \\
\text { A }\end{array}$ & 10 & 158 (35.7) & $123(27.8)$ & $144(32.6)$ & \multicolumn{2}{|c|}{ 5th Month } \\
\hline B & 16 & $151(32.8)$ & 138 (30.0) & 154 (33.5) & $17(3.7)$ & 460 \\
\hline $\mathrm{C}$ & 16 & $137(33.0)$ & $125(30.1)$ & 139 (33.5) & $14(3.4)^{*}$ & 415 \\
\hline \multicolumn{7}{|l|}{ 8th Month } \\
\hline A & 10 & 145 (33.2) & 138 (31.6) & 137 (31.4) & $17(3.9)$ & 437 \\
\hline B & 16 & $129(31.2)$ & 131 (31.7) & 139 (33.7) & $14(3.4)$ & 413 \\
\hline C & 16 & $122(30.3)$ & $109(27.1)$ & $157(39.1)$ & $14(3.5)^{*}$ & 402 \\
\hline \multicolumn{7}{|l|}{ 10th Month } \\
\hline A & 10 & $148(34.2)$ & $117(27.0)$ & $153(35.3)$ & $15(3.5)$ & 433 \\
\hline B & 16 & $127(32.2)$ & $107(27.2)$ & 148 (37.6) & $12(3.0)$ & 394 \\
\hline $\mathrm{C}$ & 16 & 118 (28.1) & 134 (31.9) & $152(36.2)$ & $16(3.8)^{*}$ & 420 \\
\hline
\end{tabular}

*The percentage of tertiary follicles was significantly higher than that of the cryopreserved tissue before grafting $(P<0.05)$.

autotransplantion of frozen-thawed ovarian tissue, and six oocytes were retrieved from the grafts (Kim et al. 2009). Animal experiments provided models for morphometric analysis of ovarian grafts. A 1-year follow-up morphometric and hormonal study showed that the recovery of ovarian function after heterotopic ovarian transplantation in rats was initially associated with hyperplasia in the area of the granulosa cell (GC) layer of the autografted antral follicles, followed by progressive loss of follicles and replacement of the ovarian parenchyma by fibrosis and epithelial cysts and lost function at 6 and 12 months (Callejo et al. 2002). Another study demonstrated that despite drastic reduction in the pool of oocytes, cyclical ovarian function was observed in ewes for nearly 2 year after ovarian tissue transplantation (Baird et al. 1999). In this study the development of follicles was observed in 10 months after ovarian tissue autotransplantation in rats.

In conclusion, the heterotopic autotransplantation of vitrified ovarian tissues from adult rat without vascular anastomosis was successful. It can maintain long-term ovarian function and exert endocrine function in target organs, in spite of the reduction in follicle pool. These results have encouraged us to research the feasibility of ovarian tissue cryostorage to young female patients that are at risk of premature ovarian failure.

Table 4 The mean number of primordial follicles in randomly selected ovarian pieces after 5 months according to groups.

\begin{tabular}{lccc}
\hline & & \multicolumn{2}{c}{ Primordial follicles } \\
\cline { 3 - 4 } Groups & $\begin{array}{c}\text { Number of } \\
\text { pieces }\end{array}$ & No. \pm s.E.M. & $\begin{array}{c}\text { Percentage } \\
\text { of control }\end{array}$ \\
\hline A (control) & 10 & $15.8 \pm 3.3$ & \\
B & 16 & $9.4 \pm 2.8^{*}$ & 59.5 \\
C & 16 & $8.7 \pm 2.7^{*}$ & 55.1 \\
\hline
\end{tabular}

*The average number of primordial follicles in recovered pieces decreased significantly in groups $B$ and $C$ compared with group $A$ after 5 months $(P<0.05)$.

\section{Materials and Methods}

\section{Animals and groups}

Ethics approval for these studies was obtained from the Animal Ethics Committee of Laboratory Animal Center of Shandong University. In this study, a total of 78 Wistar female rats (6-8weeks-old) weighing between 180 and $220 \mathrm{~g}$ were purchased from the Shandong Agriculture Science Academy. These animals were maintained in a temperature-controlled environment $\left(25^{\circ} \mathrm{C}\right)$, illuminated for $12 \mathrm{~h}$ daily. All these animals had normal estrous cycles according to vaginal cytology and were randomly divided into four groups and then were treated with different protocols. The groups and protocols are shown in Table 5.

\section{Surgical procedure}

The animals were anesthetized by an i.p. injection of $50 \mathrm{mg} / \mathrm{kg}$ pentobarbital sodium. Dorsal fur was shaved, the skin was sterilized with iodine, and a $2 \mathrm{~cm}$ medial incision was made on the dorsal skin and then the bilateral incisions of $1 \mathrm{~cm}$ were made on the dorsal body wall about $1 \mathrm{~cm}$ beside the spine. Group A (sham) underwent surgery (incisions made through the dorsal skin, body wall, and kidney capsule) but their own ovaries were left intact. The incisions in their body wall and skin were closed with stitches of nylon suture. In groups B and C, both ovaries were removed surgically. After the fat was removed, each ovary was equally cut into eight pieces in HEPES-buffered tissue culture medium 199 (TCM199, pH 7.4, Sigma) under a dissection microscope, yielding 16 ovarian blocks about $1 \times 2 \times 2 \mathrm{~mm}^{3}$ in size per rat. Four blocks were preserved in $10 \%$ formalin for histologic analyses; six blocks were immediately inserted under each kidney capsule where a small incision had been made with ophthalmologic tweezers in group B. While in group C, the ovarian blocks were cryopreserved for 2 weeks before transplantation. The transplantation procedure was the same as for group B. In group D, bilateral ovariectomy was performed without transplantation: these animals served as a castrated control group. 
Table 5 The treatment protocols for four different groups.

\begin{tabular}{|c|c|c|c|}
\hline Groups & At the beginning & 2 Weeks & 5 Months later \\
\hline $\mathrm{A}(n=15)$ & Sham operation & Sham operation & $\begin{array}{l}\text { Five animals were killed for morphologic } \\
\text { analysis of ovaries and uteri either 5, 8, } \\
\text { or } 10 \text { months after the first sham } \\
\text { operation respectively }\end{array}$ \\
\hline $\mathrm{B}(n=24)$ & $\begin{array}{l}\text { Bilateral ovariectomy } \\
\text { and autologous transplantation } \\
\text { of fresh ovarian tissues }\end{array}$ & Sham operation & $\begin{array}{l}\text { Eight animals were killed for morphologic } \\
\text { analysis of ovarian grafts and uteri either } 5,8 \text {, } \\
\text { or } 10 \text { months after transplantation respectively }\end{array}$ \\
\hline $\mathrm{C}(n=24)$ & $\begin{array}{l}\text { Bilateral ovariectomy and } \\
\text { cryopreservation of } \\
\text { ovarian tissues }\end{array}$ & $\begin{array}{l}\text { Autologous transplantation } \\
\text { of cryopreserved } \\
\text { ovarian tissues }\end{array}$ & $\begin{array}{l}\text { Eight animals were killed for morphologic } \\
\text { analysis of ovarian grafts and uteri either 5, 8, } \\
\text { or } 10 \text { months after transplantation respectively }\end{array}$ \\
\hline $\mathrm{D}(n=15)$ & Bilateral ovariectomy & Sham operation & $\begin{array}{l}\text { Five animals were killed for morphologic } \\
\text { analysis of uteri either } 5,8 \text {, or } 10 \text { months after } \\
\text { the bilateral ovariectomy respectively }\end{array}$ \\
\hline
\end{tabular}

\section{Cryopreservation and warming}

Vitrification (Hasegawa et al. 2006) was used to cryopreserve the ovarian tissues. All 16 ovarian blocks from each rat were immersed together in $1 \mathrm{ml}$ equilibration solution composed of 7.5\% ethylene glycol (EG; Sigma) and 7.5\% DMSO; (Sigma) in HEPES-buffered tissue culture medium 199 (M199; Sigma) containing $20 \%$ fetal bovine serum (FBS) for $15 \mathrm{~min}$ at room temperature, and then in $1 \mathrm{ml}$ vitrification solution for $30 \mathrm{~min}$ at $4{ }^{\circ} \mathrm{C}$. The vitrification solution was composed of $15 \%$ EG, $15 \%$ DMSO, and 0.5 M sucrose (Sigma) in M199 containing $20 \%$ FBS. Then the ovarian blocks from one rat were directly put into liquid nitrogen and immediately transferred into a $1.8 \mathrm{ml}$ plastic cryovial containing liquid nitrogen. The cap of the cryovial was closed and the cryovial was placed into a liquid nitrogen tank for storage.

When warming, the cryovial was taken out from liquid nitrogen, and the cap was opened. It took about $20 \mathrm{~s}$ for any liquid nitrogen in the cryovial to disappear. The tissues were then directly placed into a solution composed of 1.0 M sucrose in M199 with $20 \%$ FBS for 10 min at room temperature and then kept in M199 with 10\% FBS until grafting. All the procedures were carried out in a sterile hood.

\section{Vaginal cytology}

Vaginal cytology was observed to ensure that only females with normal estrous cycles were used for these experiments and to monitor the resumption of cyclic ovarian activity after transplantation. From the fourth day after surgery, vaginal irrigation samples were collected daily in all rats until typical cornified epithelial cells were observed; thereafter, vaginal irrigation was performed every 2 weeks until the animals were killed.

When getting samples, $100 \mu \mathrm{l} 0.9 \%$ saline was injected into the vagina of rat by using a sample injector with a plastic pipette. The tip of the pipette was inserted into the rat vagina, the liquid was sucked and injected several times, and then the vaginal irrigation sample was put on a glass slide (Marcondes et al. 2002). These samples were stained with hemotoxylineosin (HE) and classified as proestrus, estrus, metestrus, or diestrus (Montes \& Luque 1988).

\section{Hormone measurements}

For the measurements of $\mathrm{E}_{2}$ and progesterone, $1.5 \mathrm{ml}$ blood was collected by puncturing the carotid sinus for the rats in groups $\mathrm{A}$, $B$, and $C$ during the period of estrus-like vaginal cytological variation before being killed at 5, 8, or 10 months (the rats in group $\mathrm{D}$ at the time of death). It took $30 \mathrm{~min}$ for the blood sample to clot adequately before centrifugation. The samples were measured by ADVIA Centaur assays, which are immunoassays using direct chemiliuminescent technology (Siemens Medical Solutions Diagnostics Pty Ltd, New York, NY, USA), and the samples were processed according to the manufacturer's instructions. For $\mathrm{E}_{2}$, the assay sensitivity and range was between 10 and $1000 \mathrm{pg} / \mathrm{ml}$, and the intra- and interassay precision (mean, coefficient of variation $(\mathrm{CV})$ ) was: intra-assay, $118 \mathrm{pg} / \mathrm{ml}, \mathrm{CV}=4.3 \% ; 241 \mathrm{pg} / \mathrm{ml}, \mathrm{CV}=4.1 \% ; 556 \mathrm{pg} / \mathrm{ml}$, $\mathrm{CV}=5.1 \%$; interassay, $118 \mathrm{pg} / \mathrm{ml}, \mathrm{CV}=5.2 \% ; 241 \mathrm{pg} / \mathrm{ml}$, $\mathrm{CV}=5.3 \% ; 556 \mathrm{pg} / \mathrm{ml}, \mathrm{CV}=7.0 \%$. For progesterone, the assay sensitivity and range was between 0.21 and $60 \mathrm{ng} / \mathrm{ml}$, and the intra- and interassay precision was: intraassay, $1.5 \mathrm{ng} / \mathrm{ml}, \mathrm{CV}=8.0 \% ; 7.8 \mathrm{ng} / \mathrm{ml}, \mathrm{CV}=6.0 \% ; 24.8 \mathrm{ng} / \mathrm{ml}$, $\mathrm{CV}=4.8 \%$; interassay, $1.5 \mathrm{ng} / \mathrm{ml}, \mathrm{CV}=9.1 \% ; 7.8 \mathrm{ng} / \mathrm{ml}$, $\mathrm{CV}=7.2 \% ; 24.8 \mathrm{ng} / \mathrm{ml}, \mathrm{CV}=4.4 \%$.

\section{Morphological and histological examination}

One-third of the animals in each group were killed either 5, 8, or 10 months after transplantation respectively. The gross appearances of the uteri and grafted ovarian tissues were recorded before they were removed. Then the uterus was resected and weighed. In group $\mathrm{A}$, both ovaries were resected and equally cut into eight blocks per ovary. In groups B and C, the grafts were removed carefully. Two ovarian blocks were chosen randomly from each rat in different groups for histological examination. The samples were fixed in $10 \%$ formalin, embedded in paraffin wax, serially sectioned at $3 \mu \mathrm{m}$ (Deng et al. 2007), and stained with HE. All the sections were examined and follicles were counted and classified according to the following criteria: 1) PmF with a small primary oocyte surrounded by a single layer of flattened GCs, 2) primary follicle with a single layer of cuboidal GCs, 3) secondary follicle characterized by an enlarged granulosa up to two or 
more layers of cells, with or without irregular spaces among the cells of granulose, and 4) TF with a single antrum and cumulus oophorus. PmFs were counted only when the oocyte had a definite nuclear membrane. For larger follicles, to avoid double counting of the same, follicles were only counted in sections in which the oocyte nucleolus was visible (Israely et al. 2006). A part of the uterine tissue (about 4-6 mm long) from each rat was embedded and sectioned at $3 \mu \mathrm{m}$ (Deng et al. 2007), and the morphology of the endometrial glands was observed.

\section{Statistical analyses}

The statistical analysis was performed using the SPSS-PC program (SPSS Inc., Chicago, IL, USA). Data were pooled and $\chi^{2}$ tests were used to statistically analyze the percentage of follicles at each developmental stage between groups. The results of hormone values, uterine weight, and graft recovery were expressed as mean \pm s.E.M. and were statistically analyzed by one-way ANOVA. Statistical significance was set at $P<0.05$.

\section{Declaration of interest}

The authors declare that there is no conflict of interest that would prejudice the impartiality of this scientific work.

\section{Funding}

This work was supported by Shandong Provincial Research Fund for Young Scientists (grant no. 26010104020612).

\section{References}

Andersen CY, Rosendahl M, Byskov AG, Loft A, Ottosen C, Dueholm M, Schmidt KL, Andersen AN \& Ernst E 2008 Two successful pregnancies following autotransplantation of frozen/thawed ovarian tissue. Human Reproduction 23 2266-2272.

Baird DT, Webb R, Campbell BK, Harkness LM \& Gosden RG 1999 Longterm ovarian function in sheep after ovariectomy and transplantation of autografts stored at $-196^{\circ} \mathrm{C}$. Endocrinology $140462-471$.

Boubekri A, Gernigon-Spychalowicz T, Khammar F \& Exbraya JM 2007 Histological and immunohistological aspects of the ovarian cycle of the algerian wild sand rat, Psammomys obesus Cretzschmar, 1828. Folia Histochemica et Cytobiologica 45 41-49.

Callejo J, Salvador C, Miralles A, Vilaseca S, Lailla JM \& Balasch J 2001 Long-term ovarian function evaluation after autografting by implantation with fresh and frozen-thawed human ovarian tissue. Journal of Clinical Endocrinology and Metabolism 86 4489-4494.

Callejo J, Vilaseca S, Ordi J, Cabré S, Lailla JM \& Balasch J 2002 Heterotopic ovarian transplantation without vascular pedicle in syngeneic Lewis rats: long-term evaluation of effects on ovarian structure and function. Fertility and Sterility 77 396-402.

Candy CJ, Wood MJ \& Whittingham DG 2000 Restoration of a normal reproductive lifespan after grafting of cryopreserved mouse ovaries. Human Reproduction 15 1300-1304.

Chen SU, Chien CL, Wu MY, Chen TH, Lai SM, Lin CW \& Yang YS 2006 Novel direct cover vitrification for cryopreservation of ovarian tissues increases follicle viability and pregnancy capability in mice. Human Reproduction 21 2794-2800.
Dahm-Kähler P, Löfman C \& Fujii R 2006 An intravital microscopy method permitting continuous long-term observations of ovulation in vivo in the rabbit. Human Reproduction 21 624-631.

Demeestere I, Simon P, Emiliani S, Delbaere A \& Englert Y 2007 Fertility preservation: successful transplantation of cryopreserved ovarian tissue in a young patient previously treated for Hodgkin's disease. Oncologist 12 1437-1442.

Deng XH, Xu AR \& Chao L 2007 Effect of different sites for cryopreserved ovarian tissue implantation in rabbit. Human Reproduction 22 662-668.

Dissen GA, Lara HE, Fahrenbach WH, Costa ME \& Ojeda SR 1994 Immature rat ovaries become revascularized rapidly after autotransplantation and show a gonadotropin-dependent increase in angiogenic factor gene expression. Endocrinology 134 1146-1154.

Donnez J, Dolmans MM, Demylle D, Jadoul P, Pirard C, Squifflet J, Martinez-Madrid B \& van Langendonckt A 2004 Livebirth after orthotopic transplantation of cryopreserved varian tissue. Lancet $\mathbf{3 6 4}$ $1405-1410$

Green SH, Smith AU \& Zuckerman S 1956 The number of oocytes in ovarian autografts after freezing and thawing. Journal of Endocrinology 13 330-334.

Hasegawa A, Mochida N \& Ogasawara T 2006 Pup birth from mouse oocytes in preantral follicles derived from vitrified and warmed ovaries followed by in vitro growth, in vitro maturation, and in vitro fertilization. Fertility and Sterility 86 1182-1192.

Israely T, Nevo N, Harmelin A, Neeman M \& Tsafriri A 2006 Reducing ischaemic damage in rodent ovarian xenografts transplanted into granulation tissue. Human Reproduction 21 1368-1379.

Kim SS, Lee WS, Chung MK, Lee HC, Lee HH \& Hill D 2009 Long-term ovarian function and fertility after heterotopic autotransplantation of cryobanked human ovarian tissue: 8-year experience in cancer patients. Fertility and Sterility 91 2349-2354.

Lee DM, Yeoman RR, Battaglia DE, Stouffer RL, Zelinski-Wooten MB, Fanton JW \& Wolf DP 2004 Live birth after ovarian tissue transplant. Nature 428 137-138.

Liu J, Van der Elst J, Van den Broecke R \& Dhont M 2002 Early massive follicle loss and apoptosis in heterotopically grafted newborn mouse ovaries. Human Reproduction 17 605-611.

Liu L, Wood GA, Morikawa L, Ayearst R, Fleming C \& McKerlie C 2008 Restoration of fertility by orthotopic transplantation of frozen adult mouse ovaries. Human Reproduction 23 122-128.

Marcondes FK, Bianchi FJ \& Tanno AP 2002 Determination of the estrous cycle phases of rats: some helpful considerations. Brazilian Journal of Biology 62 609-614.

Montes GS \& Luque EH 1988 Effects of ovarian steroids on vaginal smear in the rat. Acta Anatomica 133 192-199.

Oktay K, Buyuk E, Veeck L, Zaninovic N, Xu K, Takeuchi T, Opsahl M \& Rosenwaks Z 2004 Embryo development after heterotopic transplantation of cryopreserved ovarian tissue. Lancet 363 837-840.

Parrott DMV 1960 The fertility of mice with orthotopic ovarian grafts derived from frozen tissue. Journal of Reproduction and Fertility $\mathbf{1}$ 230-241.

Sanchez M, Alama P, Gadea B, Soares SR, Simon C \& Pellicer A 2007 Fresh human orthotopic ovarian cortex transplantation: long-term result. Human Reproduction 22 786-791.

Smitz J \& Cortvrindt R 2004 First childbirth from transplanted cryopreserved ovarian tissue brings hope for cancer survivors. Lancet $\mathbf{3 6 4}$ 1379-1380.

Waterhouse T, Cox SL, Snow M, Jenkin G \& Shaw J 2004 Offspring produced from heterotopic ovarian allografts in male and female recipient mice. Reproduction 127 689-694.

Yang HY, Cox SL, Jenkin G, Findlay J, Trounson A \& Shaw J 2006 Graft site and gonadotrophin stimulation influences the number and quality of oocytes from murine ovarian tissue grafts. Reproduction 131 851-859.

Received 25 April 2009

First decision 20 May 2009

Accepted 25 June 2009 